\title{
PENOLAKAN SURAT KEPERCAYAAN (LETTER OF CREDENCE) DUTA BESAR NEGARA PENGIRIM OLEH NEGARA PENERIMA DITINJAU DARI KONVENSI WINA 1961 TENTANG HUBUNGAN DIPLOMATIK (KASUS PENOLAKAN SURAT KEPERCAYAAN DUTA BESAR INDONESIA OLEH BRAZIL)
}

\author{
Lily Husni Putri \\ Fakultas Hukum Universitas Syiah Kuala, \\ Banda Aceh
}

\begin{abstract}
According to article 4 (1) Vienna Convention 1961 on Diplomatic Relations, the sending state must make certain that the agrement of the receiving state has been given for the person it proposes to accredit as head of the mission to the receiving state. After obtaining agrement from the receiving state, the sending state will issue a letter of credence which will be presented by the person it proposes to accredit as a head of mission to the head of receiving state. In February 2015, Indonesian ambassador designate to Brazil who has been approved by Brazil was not allowed to participate in a credential presentation ceremony at Brazil's Presidential Palace. In diplomatic relations, the posponement of credential presentation of the head of mission who has been approved by the receiving state is rare. This article attempts to analyze Brazil's refusal, as the receiving state, to accept the Indonesian ambassador's letter of credence and it's compliance with Vienna Convention 1961 on Diplomatic Relations.
\end{abstract}

Keywords: postponement, letter of credence, diplomatic

\begin{abstract}
Abstrak
Menurut pasal 4 ayat (1) Konvensi Wina 1969 tentang Hubungan Diplomatik, negara pengirim harus memastikan bahwa persetujuan (agrément) negara penerima telah diberikan bagi orang yang akan diusulkan sebagai kepala misi di negara penerima. Setelah memperoleh persetujuan (agrément) dari negara penerima, negara pengirim akan mengeluarkan surat kepercayaan (letter of credence) yang akan diserahkan oleh orang yang diakreditasikan sebagai kepala misi kepada kepala negara penerima. Pada bulan Februari 2015, calon Duta Besar Indonesia untuk Brazil yang telah disetujui Brazil tidak diperkenankan mengikuti upacara penyerahan surat kepercayaan (letter of credence) di Istana Kepresidenan Brazil. Dalam hubungan diplomatik, penundaan penyerahan surat kepercayaan (letter of credence) kepala misi yang telah disetujui oleh negara penerima adalah hal yang jarang terjadi. Tulisan ini bertujuan untuk menganalisa penolakan surat kepercayaan (letter of credence) kepala misi oleh negara penerima yang sebelumnya telah disetujui khususnya dalam kasus penolakan Duta Besar Indonesia untuk Brazil menurut Konvensi Wina 1961 tentang Hubungan Diplomatik.
\end{abstract}

Lily Husni Putri, Penolakan Surat Kepercayaan (Letter of Credence) Duta Besar Negara Pengirim Oleh Negara Penerima Ditinjau dari Konvensi Wina 1961 Tentang Hubungan Diplomatik (Kasus Penolakan Surat Kepercayaan Duta Besar Indonesia Oleh Brazil) 
Kata kunci: penundaan, surat kepercayaan, diplomatik.

\section{PENDAHULUAN}

Kebiasaan suatu negara untuk mengirimkan seseorang untuk mewakili kepentingannya di negara lain adalah salah satu praktek tertua dikalangan masyarakat internasional. Beberapa bukti telah ditemukan mengenai keberadaan agen diplomatik pada zaman Mesir Pada tahun 1179 SM, Ramses II dari Mesir membuat perjanjian perdamaian dengan Hattusili II dari Kerajaan Kheta, yaitu sebuah kerajaan di Asia Kecil, dengan menggunakan bahasa Akkadi (Babylonia). Raja Iskandar Agung pernah pernah mengadakan hubungan diplomatik dengan kerajaan Maurya di India. Pada saat yang bersamaan, beberapa duta Yunani diakreditasikan pada Raja Pataliputra. Disamping itu, sejarah mencatat adanya pertukaran duta pemerintah negara Syria, Mesir, Macedonia dan Cyprus. Pada abad ke-7 SM, Raja Harsashawardhana dari India telah membuka hubungan kuno, India kuno dan Cina kuno. antara Maharaja Ashoka dengan

diplomatik dengan Cina. ${ }^{1}$ Di Indonesia, kerajaan-kerajaan di wilayah Nusantara telah mengadakan hubungan dengan India, Cina dan negara-negara Timur Tengah bahkan sebelum negara-negara Eropa mengadakan hubungan diplomatik dengan negara-negara lain di sekitarnya. Pada tahun 1286, Maharaja Tiongkok yang bernama Kubilai Khan mengirimkan dutanya ke Singosari. 2 Sementara di Eropa, Inggris, Prancis, Spanyol dan Jerman saling mengirimkan perwakilan tetap ke negara masingmasing pada tahun $1500 .^{3}$

Awalnya peraturan-peraturan yang mengatur hubungan diplomatik didasarkan pada kebiasaan internasional dan praktek negara-negara. Baru pada abad ke19, pengaturan hubungan diplomatik dibicarakan dalam Kongres Wina tahun 1815 dan

1 Widodo, Hukum Diplomatik dan Konsuler Pada Era Globalisasi, CV Aswaja Pressindo, Yogyakarta, 2012, hlm. 19

2 Syahmin Ak, Hukum Diplomatik: Suatu Pengantar, Armico, Bandung, 1998, hlm.16

${ }^{3}$ John O'Brien, International Law, Cavendish Publishing Limited, London, 2001, hlm. 297

Lily Husni Putri, Penolakan Surat Kepercayaan (Letter of Credence) Duta Besar Negara Pengirim Oleh Negara Penerima Ditinjau dari Konvensi Wina 1961 Tentang Hubungan Diplomatik (Kasus Penolakan Surat Kepercayaan Duta Besar Indonesia Oleh Brazil) 
p-ISSN: 1693-766X ; e-ISSN: 2579-4663, Vol. 26, No. 2, Agustus 2017

Kongres Aix la Chapelle tahun 1818. Berkuasa Penuh (Plenipotentiary Kongres Wina tahun 1818 Conference) yang mengesahkan merupakan tonggak sejarah Konvensi Wina tentang Hubungan diplomasi moderen karena telah Diplomatik (Vienna Convention on berhasil mengatur dan membuat Diplomatic Relations). Kemudian prinsip-prinsip hukum diplomatik pada tanggal 18 April 1963 diadakan secara sistematis seperti lagi konferensi serupa dan penggolongan Kepala Perwakilan menghasilkan Konvensi Wina Diplomatik. Penggolongan Kepala tentang Hubungan Konsuler (Vienna Perwakilan Diplomatik tersebut Convention on Consular Relations) adalah sebagai berikut: 4

yang disahkan pada tanggal 22 April
a. Duta-duta Besar dan para Utusan (Ambassadors and Legates)

Pada umumnya pengangkatan duta besar sebagai

b. Menteri Berkuasa Penuh dan kepala perwakilan diplomatik negara Duta Luar Biasa (Minister pengirim di negara penerima Plenipotentiary and Envoy Extraordinary)
c. Kuasa Usaha (Charge d'Affaires)

Dua tahun setelah didirikan, dilakukan oleh dan atas nama kepala negara dengan mendapat usul dari menteri luar negeri dan saran dari para pejabat negara lainnya bila dianggap perlu sesuai Perserikatan Bangsa-Bangsa (PBB) membentuk Komisi Hukum dengan konstitusi negara masingmasing. 6 Nama calon duta besar Internasional (International Law yang telah ditetapkan tersebut harus Commission/ILC) yang bertugas mendapat persetujuan dari negara membahas perkembangan dan penerima (agrément). Setelah kodifikasi hukum internasional mendapatkan agrément, kepala termasuk hukum diplomatik. Atas negara pengirim mengeluarkan surat prakarsa PBB, pada tanggal 2 Maret kepercayaan (letter of credence). - 14 April 1961 di Wina, Austria diadakan Konferensi Menteri

Hubungan diplomatik antar negara tidak selalu berjalan dengan

${ }^{4}$ Sumaryo Suryokusumo, Hukum ${ }^{5}$ Ibid, hlm. 23-24

${ }^{6}$ B. Sen, A Dipomat Handbook's of Diplomatik dan Konsuler Jilid I, International Law and Practice, Martinus Tatanusa, Jakarta, 2013, hlm. 18-19 Nijhoff, The Hague, 1965, hlm. 24

Lily Husni Putri, Penolakan Surat Kepercayaan (Letter of Credence) Duta Besar Negara Pengirim Oleh Negara Penerima Ditinjau dari Konvensi Wina 1961 Tentang Hubungan Diplomatik (Kasus Penolakan Surat Kepercayaan Duta Besar Indonesia Oleh Brazil) 
p-ISSN: 1693-766X ; e-ISSN: 2579-4663, Vol. 26, No. 2, Agustus 2017

mulus. Beberapa waktu lalu mati oleh regu tembak di hubungan diplomatik antara Nusakambangan. ${ }^{8}$

Indonesia dan Brazil yang telah lama Pada 31 Juli 2004, petugas terjalin dan saling menguntungkan tersebut mengalami ketegangan terkait dua warga negara Brazil yang dijatuhi hukuman mati karena kejahatan penyelundupan narkotika.

Pada tahun 2003, Marco Archer Cardoso Moreira warga negara Brazil yang berumur 53 tahun ditangkap di bandara Soekarno-Hatta karena polisi menemukan 13,4 kg kokain yang disembunyikan di dalam pipa kerangka pesawat gantole yang dibawanya. Majelis hakim Pengadilan Negeri Tangerang menjatuhkan hukuman mati terhadap Marco pada Juni 2004. Marco mengajukan banding tetapi Pengadilan Tinggi Banten menolak permohonan banding pada Januari 2005. Ditingkat Mahkamah Agung (MA), putusan terhadap Marco tetap hukuman mati. Pengajuan grasinya pada 30 Desember 2014 pun ditolak Presiden Joko Widodo. 7 Pada tanggal 18 Januari 2015 Marco dieksekusi

${ }^{7}$ Republika, "Kisah Terpidana Mati (1): dari Pilot Jadi Bandar Narkotika" diunduh dari http://www.republika.co.id/berita/nasi onal/hukum/15/01/17/niabv3-kisahterpidana-mati-1-dari-pilot-jadi-bandarnarkotika. Bea dan Cukai bandara Soekarno-
Hatta menangkap Rodrigo Gularte karena menyelundupkan $19 \mathrm{~kg}$ kokain dengan cara disembunyikan dalam papan selancar miliknya. 9 Rodrigo Gularte dijatuhkan hukuman mati oleh Pengadilan Negeri Tangerang pada tanggal 7 Februari 2005 dan dikuatkan oleh Pengadilan Tinggi Banten pada tanggal 10 Mei 2005. Dia mengajukan grasi, tetapi permohonan grasinya ditolak oleh Presiden Joko Widodo melalui Keppres Nomor 5/G pada tanggal 5 Januari 2015. 10 Rodrigo Gularte Lily Husni Putri, Penolakan Surat Kepercayaan (Letter of Credence) Duta Besar Negara Pengirim Oleh Negara Penerima Ditinjau dari Konvensi Wina 1961 Tentang Hubungan Diplomatik (Kasus Penolakan Surat Kepercayaan Duta Besar Indonesia Oleh Brazil) 
p-ISSN: 1693-766X ; e-ISSN: 2579-4663, Vol. 26, No. 2, Agustus 2017

dieksekusi mati di Nusakambangan pada tanggal 29 April 2015.11

Brazil memprotes keras eksekusi mati terhadap warganya dengan memanggil pulang duta besarnya. ${ }^{12}$ Eksekusi tersebut juga mengakibatkan Presiden Brazil Dilma Rouseff menolak menerima surat kepercayaan (letter of credence) duta besar Indonesia untuk Brazil, Toto Riyanto. Padahal pengangkatan Toto Riyanto sebagai calon duta besar Indonesia untuk Brazil sebelumnya telah disetujui oleh pemerintah Brazil. Duta Besar Republik Indonesia untuk Brazil Toto Riyanto tiba di Brasilia, Brazil pada tanggal 25 November 2014. Pada tanggal 25 November 2014, Duta Besar Republik Indonesia untuk Brazil Toto Riyanto menyerahkan salinan surat kepercayaan (letter of credence) kepada Kementerian Luar Negeri Brazil. Pada tanggal 19 Februari

11 Kompas.com, "Hingga Saat Terakhir Rodrigo Gularte Tak Sadar Akan Dieksekusi" diunduh tanggal 23 Mei 2015 dari http://internasional.kompas.com/read/ 2015/04/30/11464971/Hingga.Saat.Te rakhir.Rodrigo.Gularte.Tak.Sadar.Akan. Dieksekusi.

12Tempo, "Protes Eksekusi, Dubes Brasil Ditarik dari Jakarta", diunduh tanggal 24 Mei 2015 dari https://m.tempo.co/read/news $/ 2015 / 0$ $1 / 18 / 063635680 /$ protes-eksekusidubes-brasil-ditarik-dari-jakarta. Lily Husni Putri, Penolakan Surat Kepercayaan (Letter of Credence) Duta Besar Negara Pengirim Oleh Negara Penerima Ditinjau dari Konvensi Wina 1961 Tentang Hubungan Diplomatik (Kasus Penolakan Surat Kepercayaan Duta Besar Indonesia Oleh Brazil)
2015, Duta Besar Indonesia untuk Brazil Toto Riyanto mendapat undangan berupa nota diplomatik dari Kementerian Luar Negeri Brazil untuk mengikuti kegiatan penyerahan surat kepercayaan (letter of credence) pada tanggal 20 Februari 2015 pukul 09.00 pagi waktu setempat. Toto Riyanto hadir pada kegiatan tanggal 20 Februari 2015 di Istana Kepresidenan Brazil (Palacio do Planalto) untuk menyerahkan surat kepercayaan (letter of credence). ${ }^{13}$ Toto Riyanto masuk ke istana melewati jajar kehormatan sesuai dengan petunjuk dari protokol dan mendapat briefing tentang penyerahan surat kepercayaan (letter of credence). Selain Toto Riyanto, juga hadir lima orang duta besar dari Venezuela, El Salvador, Panama, Senegal dan Yunani yang sama-sama akan menyerahkan surat kepercayaan (letter of credence) kepada Presiden Brazil Dilma Rouseff. Berdasarkan rencana, yang akan menyerahkan terlebih dahulu adalah Toto Riyanto. Tetapi Toto Riyanto dipanggil oleh

13 Antara News, "Soal Penarikan Duta Besar Indonesia untuk Brazil", diunduh tanggal 25 April 2017, dari http://www.antaranews.com/berita/48 1892/soal-penarikan-duta-besarindonesia-untuk-brasil. surat kepercayaan (letter of credence) 
p-ISSN: 1693-766X ; e-ISSN: 2579-4663, Vol. 26, No. 2, Agustus 2017

Menteri Luar Negeri Brazil dan Convention 1961 on Diplomatic dibawa ke dalam suatu ruangan. Relations). 16 Dalam bidang Menteri Luar Negeri Brazil perdagangan, rencana ekspor daging menyampaikan bahwa penyerahan sapi dari Brazil ditunda surat kepercayaan (letter of credence) pembahasannya. Rencana untuk Indonesia ditunda dan tidak pembelian lanjutan 8 unit pesawat mengetahui sampai kapan Super Tucano versi EMB-314/A29B penundaan itu berlangsung. Menteri dari 16 unit yang disepakati pun Luar Negeri Brazil juga tidak terancam batal akibat dari memberikan alasan penundaan hubungan Indonesia - Brazil yang tersebut. Namun diduga kuat memanas terkait hukuman mati penundaan tersebut ada kaitannya terhadap dua warga negara Brazil. ${ }^{17}$ dengan eksekusi mati warga negara Brazil. ${ }^{14}$

Indonesia menyampaikan menjelaskan dan menganalisa penolakan surat kepercayaan (letter reaksi keras atas penolakan Presiden Brazil Dilma Rouseff untuk menerima surat kepercayaan (letter of credence) dari Indonesia yang menugaskan Toto Riyanto sebagai duta besar di negara tersebut. ${ }^{15}$ Menteri Luar Negeri Indonesia Retno Marsudi menyatakan bahwa tindakan Brazil tersebut melanggar Konvensi Wina 1961 tentang of credence) seorang pejabat diplomatik negara pengirim oleh negara penerima yang sebelumnya telah mendapat persetujuan dari negara penerima, khususnya dalam kasus penolakan surat kepercayaan (letter of credence) duta besar Indonesia untuk Brazil ditinjau dari Konvensi Wina 1961 tentang Hubungan Diplomatik (Vienna Hubungan Diplomatik (Vienna Convention 1961 on Diplomatic Relations).

14 Antara News, "Ini Kronologis Penolakan Surat Kepercayaan",diakses tanggal 30 Mei 2017, dari http://www.antaranews.com/berita/48 $1610 /$ ini-kronologis-penolakan-suratkepercayaan-dubes-toto,

15 Antara News, "Soal Penarikan Duta Besar Untuk Brazil", diunduh tanggal $24 \quad$ April 2017 dari http://www.antaranews.com/berita/48 1892/soal-penarikan-duta-besarindonesia-untuk-brasil.

${ }^{16} \mathrm{Ibid}$

17 Merdeka, "TNI AU Berharap Pembelian Super Tucano dari Brazil Jalan Terus", diunduh tanggal 24 April 2017 dari https://www.merdeka.com/peristiwa/tn i-au-berharap-pembelian-super-tucanodari-brasil-jalan-terus.html.

Lily Husni Putri, Penolakan Surat Kepercayaan (Letter of Credence) Duta Besar Negara Pengirim Oleh Negara Penerima Ditinjau dari Konvensi Wina 1961 Tentang Hubungan Diplomatik (Kasus Penolakan Surat Kepercayaan Duta Besar Indonesia Oleh Brazil) 
p-ISSN: 1693-766X ; e-ISSN: 2579-4663, Vol. 26, No. 2, Agustus 2017

\section{PEMBAHASAN}

\section{Fungsi Perwakilan Diplomatik}

Secara tradisional, fungsi perwakilan diplomatik, baik duta besar maupun para pejabat diplomatiknya adalah mewakili negara pengirim di negara penerima dan bertindak sebagai penghubung antara pemerintah kedua negara. ${ }^{18}$ Palmer dan Perkins dalam bukunya yang berjudul "International Relations: The World Community in Transition" menyatakan bahwa perwakilan diplomatik adalah mata dan telinga negara pengirim di negara penerima. Tugas utamanya adalah memajukan kepentingan negara pengirim di negara penerima dan melaporkan segala kejadian dan kegiatan yang penting bagi hubungan kedua negara kepada negara penerima. 19 Menurut Oppenheim fungsi perwakilan diplomatik adalah negosiasi yaitu bertindak sebagai perantara antara negara pengirim dengan negara penerima, observasi yaitu memperhatikan segala kejadian di negara penerima dan proteksi yaitu

18 B. Sen, Op.Cit, hlm. 46

19 Norman D. Palmer \& Howard C. Perkins, International Relations: The World Community in Transition, Houghton Mifflin, Boston, Massachusetts, 1957, hlm. 84

Lily Husni Putri, Penolakan Surat Kepercayaan (Letter of Credence) Duta Besar Negara Pengirim Oleh Negara Penerima Ditinjau dari Konvensi Wina 1961 Tentang Hubungan Diplomatik (Kasus Penolakan Surat Kepercayaan Duta Besar Indonesia Oleh Brazil) melindungi warga negara dan properti negara pengirim di negara penerima. 20 Fungsi perwakilan diplomatik berdasarkan pasal 3 ayat (1) Konvensi Wina 1961 tentang Hubungan Diplomatik (Vienna Convention 1961 on Diplomatic Relations) antara lain (inter alia) adalah sebagai berikut:21

a. Mewakili negara pengirim di negara penerima

b. Melindungi kepentingan negara pengirim dan warga negara pengirim di negara penerima dalam batas-batas yang diperbolehkan oleh hukum internasional

20 R. Jennings \& A. Watts, Oppenheim's International Law Volume I: Peace, 9th Edition, Longman, London, New York, 1997, hlm. 556-557

21 Pasal 3 ayat (1) Konvensi Wina 1961 tentang Hubungan Diplomatik (Vienna Convention 1961 on Diplomatic Relations) menyatakan:

1. The functions of a diplomatic mission consist inter alia in:

(a). Representing the sending state in the receiving state

(b). Protecting in the receiving state the interest of the sending state and of its nationals, within the limits of international law

(c). Negotiating with the government of the receiving state

(d). Ascertaining by all lawful means conditions and developments in the receiving state, and reporting thereon to the government of the sending state

(e). Promoting friendly relations between the sending state and the receiving state, and developing their economic, cultural and scientific relations 
c. Melakukan perundingan dengan pemerintah negara penerima

d. Memberikan laporan kepada pemerintah negara pengirim mengenai keadaan-keadaan dan perkembanganperkembangan negara dengan cara yang dibenarkan oleh hukum internasional

e. Meningkatkan persahabatan antara negara pengirim dengan negara penerima serta mengembangkan dan memperluas hubungan hubunganekonomi, kebudayaan dan ilmu pengetahuan

Berdasarkan pada ketentuan tersebut dapat disimpulkan bahwa fungsi perwakilan diplomatik adalah representasi, proteksi, negosiasi, pelaporan dan peningkatan hubungan persahabatan.

a. Representasi

Tugas utama diplomat adalah mewakili negara pengirim di negara penerima serta melindungi kepentingan dan warga negara pengirim di negara penerima. Sebagai wakil resmi negara, diplomat harus menghadiri penerima yang diperoleh

undangan negara penerima dalam kegiatan-kegiatan khusus. Diplomat bertindak sebagai saluran komunikasi antara negara pengirim dengan negara penerima. Dengan demikian tingkah laku diplomat mencerminkan perilaku negara pengirim. Gerard Von Glahn menegaskan bahwa selain bertugas sebagai wakil negara pengirim di negara penerima dalam hal-hal yang bersifat ceremonial, diplomat juga berhak mengajukan protes dan penyelidikan (inquiries) atau mengajukan pertanyaan kepada negara penerima. ${ }^{22}$ Oleh karena itu diplomat juga mewakili negara pengirim dalam proses hukum di negara penerima baik sebagai penggugat atau tergugat. ${ }^{23}$

b. Proteksi

Melindungi kepentingan negara pengirim dan warga negara pengirim dalam batas-batas yang diperkenankan oleh hukum internasional adalah tugas

22 Gerhard Von Glahn, Law Among Nations: An Introduction to Public International Law, Mac Millan Publishing, New York, 1976, hlm. 39

${ }^{23}$ Castiglioni vs Federal People's Republic of Yugoslavia Case No. 43 (1952), Tribunal of Rome, Italy

Lily Husni Putri, Penolakan Surat Kepercayaan (Letter of Credence) Duta Besar Negara Pengirim Oleh Negara Penerima Ditinjau dari Konvensi Wina 1961 Tentang Hubungan Diplomatik (Kasus Penolakan Surat Kepercayaan Duta Besar Indonesia Oleh Brazil) 
p-ISSN: 1693-766X ; e-ISSN: 2579-4663, Vol. 26, No. 2, Agustus 2017

perwakilan diplomatik. ${ }^{24}$ Pemberian perlindungan tersebut berkaitan dengan hak-hak asasi warga negara pengirim di negara penerima, termasuk hak milik dan kehormatan. ${ }^{25}$ Diplomat harus siap membantu apabila warga negara pengirim terlibat masalah hukum di negara penerima. Intervensi pada tingkat diplomatik dapat melindungi warga negara penerima dari hal-hal yang merugikan mereka dan membela mereka dari ketidakadilan dengan cara-cara yang diperkenankan oleh hukum. ${ }^{26}$ Contoh upaya proteksi yang dilakukan perwakilan diplomatik Indonesia di luar negeri adalah memberikan bantuan hukum kepada Nuruzahri bin Ibrahim, seorang warga negara Indonesia asal Aceh yang berusia 25 tahun. Pada tahun 2013, Nuruzahri bin Ibrahim didakwa melakukan pengedaran narkoba jenis methamphetamine seberat 191,6 gram dan turut serta dalam proses produksi narkoba di sebuah unit kondominium di daerah

${ }^{24}$ Pasal 3 ayat (1) b Konvensi Wina 1961 tentang Hubungan Diplomatik (Vienna Convention 1961 on Diplomatic Relations)

25 Widodo, Op.Cit, hlm. 54

26 Gheorge Iacob, Introduction in Diplomacy, Foundation Axis Publishing House, Iasi, 1997, hlm. 345

Lily Husni Putri, Penolakan Surat Kepercayaan (Letter of Credence) Duta Besar Negara Pengirim Oleh Negara Penerima Ditinjau dari Konvensi Wina 1961 Tentang Hubungan Diplomatik (Kasus Penolakan Surat Kepercayaan Duta Besar Indonesia Oleh Brazil)
Kajang, Selangor, Malaysia, yang diancam dengan hukuman mati. Hakim Mahkamah Tinggi Shah Alam membebaskan Nuruzahri bin Ibrahim dari hukuman mati setelah jaksa penuntut umum menerima pembelaan tertulis dari pengacara yang ditunjuk Kedutaan Besar Republik Indonesia (KBRI) Kuala Lumpur dan mencabut tuntutannya terhadap Nuruzahri bin Ibrahim. KBRI Kuala Lumpur kemudian menerbitkan Surat Perjalanan Laksana Paspor (SPLP) bagi Nuruzahri bin Ibrahim dan memproses kepulangannya ke Indonesia. ${ }^{27}$

c. Negosiasi

Perwakilan diplomatik juga mempunyai tugas untuk melakukan negosiasi mengenai berbagai masalah yang menjadi kepentingan negara pengirim di negara penerima. Dalam sejarah hubungan internasional, negosiasi dianggap sebagai salah satu tugas inti diplomasi. Pengertian negosiasi dalam konteks hubungan internasional adalah pembicaraan

27 Antaranews.com, "Nuruzahri Bebas Ancaman Hukuman Mati di Malaysia”, diunduh tanggal 20 Mei 2017 dari

http://www.antaranews.com/berita/40 9467/nuruzahari-bebas-ancamanhukuman-mati-di-malaysia. 
p-ISSN: 1693-766X ; e-ISSN: 2579-4663, Vol. 26, No. 2, Agustus 2017

antar wakil negara untuk Karena itu, pada waktu ia harus menyelesaikan masalah atau topik melakukan negosiasi sepanjang dianggap layak bagi negaranya, tertentu secara damai. ${ }^{28}$ Didalam haruslah didalam batas-batas dan negosiasi, peranan diplomat sangat menurut syarat-syarat yang sudah penting. Pada waktu melakukan negosiasi diplomat harus selalu mengajukan kemungkinan tawaran yang paling baik sesuai dengan kepentingan negara pengirim. Disamping itu diplomat juga harus yakin bahwa setiap penyelesaian yang sudah dicapai mempunyai arti yang praktis dan bukan saja mampu untuk menyelesaikan pertikaian tetapi juga mencegah setiap pertikaian mengenai masalah tersebut dimasa mendatang. 29 Mengenai tugas diplomat sebagai negosiator, Hugh Gibson, seorang diplomat Amerika Serikat menyatakan:30

"Sesungguhnya menang kalah dalam negosiasi bukan merupakan masalah didalam diplomasi. Diplomat tidak boleh melupakan bahwa masalah yang sedang ditangani itu hanya relatif penting sifatnya, karena negosiasi itu hanya suatu rangkaian proses yang masih belum tuntas yang harus dibicarakan lagi dengan pihak lain dalam tahun-tahun mendatang. ditentukan. Hal itu penting untuk menghilangkan kebencian dan rasa tidak adil didalam negosiasinegosiasi berikutnya. Yang penting semua pihak merasa puas sehingga mereka dapat membawanya kedalam negosiasi yang akan datang dengan harapan dapat dicapai suatu persetujuan dan sebaliknya bukan suatu hasrat untuk balas dendam karena kekalahan yang tidak dapat dielakkan."

Negosiasi sering dianggap sebagai gabungan cara ilmiah dan artistik karena diplomat harus memiliki pengetahuan, pengalaman dan bakat untuk menjadi negosiator yang baik. ${ }^{31}$ Cambon menyatakan sebagai berikut:

"The art of diplomat stems from the art of governing, for every diplomatic action ends in negotiation, and who ever says negotiation means, at least in part, compromise." 32

$\begin{array}{llr}\text { Dari pernyataan } & \text { di atas } & \text { dapat } \\ \text { disimpulkan } & \text { bahwa } & \text { seni } \\ \text { berdiplomasi } & \text { adalah } & \text { seni }\end{array}$

28 Widodo, Op.Cit, hlm. 56

29 GVG Khrisnamurty, Modern Diplomacy, Dialect and Dimension, Sagar Publication, New Delhi, 1968, hlm. 340341

30 Hugh Gibson, The Road to Foreign Policy, Doubleday, New York, 1944, hlm. 77

\footnotetext{
31 Dumitru Mazilu, Treaty Regarding Negotiation: Theory and Practice, Lumina Lex Publishing House, Bucharest, 2002, hlm. 460

32 Frederick H. Hartmann, The Relations of Nations, Macmillan Publishing Company, New York, 1987, hlm. 94
}

Lily Husni Putri, Penolakan Surat Kepercayaan (Letter of Credence) Duta Besar Negara Pengirim Oleh Negara Penerima Ditinjau dari Konvensi Wina 1961 Tentang Hubungan Diplomatik (Kasus Penolakan Surat Kepercayaan Duta Besar Indonesia Oleh Brazil) 
p-ISSN: 1693-766X ; e-ISSN: 2579-4663, Vol. 26, No. 2, Agustus 2017

berkompromi; mengetahui bertentangan dengan hukum. 34 bagaimana dan kapan berkompromi Menurut publikasi Departemen Luar merupakan pertanda seorang Negeri Amerika Serikat, diplomat negosiator ulung.

Seiring dengan perkembangan diharapkan mampu mengamati, menganalisa dan melaporkan politik internasional dan kemajuan kepada negara pengirim mengenai telekomunikasi dan transportasi, kondisi politik, sosial dan ekonomi saat ini fungsi negosiasi perwakilan diplomatik mengalami penyempitan serta kecenderungan-kecenderungan masyarakat atau negara penerima karena fungsi negosiasi ini hanya diwujudkan dalam bentuk yang dianggap signifikan. Hal-hal penyediaan sarana dan perancangan yang dilaporkan diantaranya adalah naskah perundingan sedangkan program legislatif, opini publik, negosiasi yang sebenarnya kondisi pasar, statistik perdagangan, dilakukan oleh menteri luar negeri keuangan, produksi, pertanian, tenaga kerja, kehutanan, perikanan, atau kepala negara/kepala pertambangan, kekayaan alam, pemerintahan. Negosiasi multilateral pelayaran, pengangkutan, legislasi, pun lebih sering dilakukan oleh tarif dan hukum. ${ }^{35}$ Fungsi pelaporan menteri luar negeri atau misi khusus yang diberi tugas untuk melaksanakan negosiasi. ${ }^{33}$

\section{d. Pelaporan}

Fungsi perwakilan diplomatik lainnya yang juga penting adalah memberikan laporan kepada negara pengirim mengenai keadaan dan perkembangan negara penerima dengan cara-cara yang tidak

33 S.L. Roy, Diplomasi, Rajawali, tidak sama dengan kegiatan spionase karena informasi yang diperoleh oleh perwakilan diplomatik adalah informasi resmi yang

34 Pasal 3 ayat (1) huruf d Konvensi Wina 1961 tentang Hubungan Diplomatik (Vienna Convention 1961 on Diplomatic Relations) menyatakan:

(1). "The functions of a diplomatic mission consist inter alia in:

$\cdots$

d. ascertaining by all lawful means conditions and developments in the receiving state, and reporting thereon to the government of the sending state"

35 The Foreign Services of the United States Department of State Publication 3612, Foreign Services Series 6, Government Printing Office, Washington DC, 11 Agustus 1946, http://www.dfa.gov.za/foreign/forrep/fo rf.htm Jakarta, 1995, hlm. 184

Lily Husni Putri, Penolakan Surat Kepercayaan (Letter of Credence) Duta Besar Negara Pengirim Oleh Negara Penerima Ditinjau dari Konvensi Wina 1961 Tentang Hubungan Diplomatik (Kasus Penolakan Surat Kepercayaan Duta Besar Indonesia Oleh Brazil) 
p-ISSN: 1693-766X ; e-ISSN: 2579-4663, Vol. 26, No. 2, Agustus 2017

dikeluarkan oleh pihak negara penerima dengan negara pengirim penerima misalnya dari kementerian harus mengetahui karakter masingluar negeri negara penerima, media masing negara dari berbagai sisi massa dan publikasi ilmiah.

\section{e. Meningkatkan Hubungan Persahabatan Antara Negara Penerima Dengan Negara Pengirim}

Meningkatkan hubungan persahabatan dan kerja sama dalam berbagai bidang antara negara penerima dengan negara pengirim adalah salah satu fungsi perwakilan diplomatik yang juga penting. Oleh karena itu perwakilan diplomatik memainkan peranan penting dalam menjalin hubungan bilateral antara negara pengirim dengan negara penerima berdasarkan prinsip moral, fairness dan lawful. Dalam mengadakan kerjasama ekonomi dan perdagangan, kedua negara harus mempertimbangkan asas saling menguntungkan (mutual benefit), saling menghormati (mutual respect), saling tidak mencampuri urusan dalam negeri masing-masing (non-interference) dan saling pengertian (mutual understanding). 36

Agar hubungan persahabatan dan kerjasama dapat berjalan dengan baik, antara negara hlm. 76

${ }^{36}$ Sumaryo Suryokusumo, Op.Cit, Lily Husni Putri, Penolakan Surat Kepercayaan (Letter of Credence) Duta Besar Negara Pengirim Oleh Negara Penerima Ditinjau dari Konvensi Wina 1961 Tentang Hubungan Diplomatik (Kasus Penolakan Surat Kepercayaan Duta Besar Indonesia Oleh Brazil) nasional. ${ }^{37}$ Duta besar sebagai kepala perwakilan diplomatik yang bertugas untuk meningkatkan pengertian antara negara pengirim dengan negara penerima bukan hanya berhubungan dengan pemerintah negara penerima tetapi juga dengan media massa negara penerima untuk menjelaskan mengenai maksud, harapan dan kehendak negara pengirim kepada rakyat negara penerima. ${ }^{38}$

Frasa 'inter alia' (antara lain) yang terdapat dalam pasal 3 ayat (1) menunjukkan bahwa Konvensi Wina 1961 tentang Hubungan Diplomatik (Vienna Convention 1961 on Diplomatic Relations) tidak begitu rinci mengatur fungsi perwakilan diplomatik, yang artinya ada fungsi lain perwakilan diplomatik selain yang disebutkan di dalam pasal ini. Fungsi lain tersebut tergantung dari kebiasaan dan praktek yang berlaku atau sesuai dengan situasi tertentu di negara penerima. Sebagai contoh apabila negara pengirim tidak

37 Widodo, Op.Cit, hlm. 60

38 Sumaryo Suryokusumo, Loc Cit

misalnya agama, kebudayaan, kecenderungan, termasuk moral

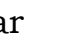


p-ISSN: 1693-766X ; e-ISSN: 2579-4663, Vol. 26, No. 2, Agustus 2017

membuka perwakilan konsuler di penerima serta memajukan negara penerima maka fungsi kepentingan perdagangan, industri, perwakilan konsuler misalnya ekonomi, dan kebudayaan. mengeluarkan paspor, pencatatan Meskipun demikian, pemilahan kematian, kelahiran, perkawinan fungsi perwakilan diplomatik dengan dan perceraian warga negara fungsi perwakilan konsuler secara pengirim di negara penerima bisa konkrit sulit dilakukan karena dilakukan oleh perwakilan dalam praktek fungsi tersebut dapat diplomatik. Demikian juga dilakukan oleh salah satu sebaliknya, apabila negara pengirim perwakilan. ${ }^{39}$ tidak membuka perwakilan diplomatik tetapi hanya membuka perwakilan konsuler di negara penerima maka fungsi perwakilan diplomatik dapat dilakukan oleh perwakilan konsuler. Hal ini ditegaskan didalam pasal 3 ayat (2) Konvensi Wina 1961 tentang Hubungan Diplomatik (Vienna Convention 1961 on Diplomatic Relations):

"Nothing in the present Convention shall be construed as preventing the performance of consular functions by a diplomatic mission."

Memang terdapat perbedaan antara fungsi perwakilan diplomatik dengan perwakilan konsuler. Perwakilan diplomatik menangani persoalan politik sedangkan perwakilan konsuler menangani urusan non politis yang lebih mengutamakan fungsi perlindungan kepentingan warga negara pengirim di negara perwakilan diplomatik diperluas seperti yang ditentukan dalam pasal 5 Keputusan Presiden Republik Indonesia Nomor 108 Tahun 2003 tentang Organisasi Perwakilan Republik Indonesia di Luar Negeri yaitu sebagai berikut:

a. Peningkatan dan pengembangan kerja sama politik dan keamanan, ekonomi, sosial dan budaya dengan negara penerima dan/atau organisasi internasional

b. Peningkatan persatuan dan kesatuan, serta kerukunan antara sesama warga negara Indonesia di luar negeri

39 Eileen Denza, Diplomatic Law: A Commentary on the Vienna Convention on Diplomatic Relations, 2nd Edition, Oxford University Press, New York, 2002 hlm. 33

Lily Husni Putri, Penolakan Surat Kepercayaan (Letter of Credence) Duta Besar Negara Pengirim Oleh Negara Penerima Ditinjau dari Konvensi Wina 1961 Tentang Hubungan Diplomatik (Kasus Penolakan Surat Kepercayaan Duta Besar Indonesia Oleh Brazil) 
c. Pengayoman, pelayanan, mewakili dan memperjuangkan perlindungan dan pemberian kepentingan bangsa, negara dan bantuan hukum dan fisik pemerintah Republik Indonesia serta kepada warga negara melindungi warga negara Republik Indonesia dan badan hukum Indonesia, badan hukum Indonesia Indonesia, dalam hal terjadi di negara penerima dan/atau ancaman dan/atau masalah organisasi internasional sesuai hukum di negara penerima, dengan kebijakan politik dan luar sesuai dengan peraturan negeri pemerintah Republik perundang-undangan Indonesia, peraturan perundangnasional, hukum undangan nasional, hukum internasional, dan kebiasaan internasional, dan kebiasaan internasional internasional.

d. Pengamatan, penilaian dan pelaporan mengenai situasi dan kondisi negara penerima

e. Konsuler dan protokol

f. Perbuatan untuk dan atas nama negara dan pemerintah Republik Indonesia dengan negara penerima

g. Kegiatan manajemen kepegawaian, keuangan,

\section{Keistimewaan dan Kekebalan Pejabat Diplomatik}

Diplomat agar dapat menjalankan tugas dan fungsinya dengan lancar, diberikan kekebalan dan keistimewaan diplomatik. Menurut Protokol II pedoman Tertib Diplomatik Departemen Luar Negeri perlengkapan, pengamanan Republik Indonesia, isitilah internal Perwakilan, kekebalan mengandung dua pengertian yaitu kekebalan komunikasi dan persandian (immunity) atau imunitas dan tidak h. Fungsi-fungsi lain sesuai dapat diganggugugat atau dengan hukum dan praktek inviolabilitas (inviolability). internasional Inviolabilitas (inviolability) adalah kekebalan diplomat terhadap alatFungsi tersebut dilaksanakan alat kekuasaan negara penerima dan untuk menjalankan tugas pokok kekebalan terhadap segala gangguan perwakilan diplomatik sebagaimana yang mengakibatkan kerugian. yang diatur dalam pasal 4 yaitu Pengertian tersebut bermakna Lily Husni Putri, Penolakan Surat Kepercayaan (Letter of Credence) Duta Besar Negara Pengirim Oleh Negara Penerima Ditinjau dari Konvensi Wina 1961 Tentang Hubungan Diplomatik (Kasus Penolakan Surat Kepercayaan Duta Besar Indonesia Oleh Brazil) 
p-ISSN: 1693-766X ; e-ISSN: 2579-4663, Vol. 26, No. 2, Agustus 2017

bahwa diplomat berhak memperoleh perlindungan dari alat-alat negara penerima. 40 Disamping diplomat, inviolabilitas juga berlaku pada gedung perwakilan diplomatik, arsip dan dokumen lainnya, serta tempat kediaman diplomat. ${ }^{41}$ Sedangkan kekebalan (immunity) diartikan sebagai kekebalan terhadap yurisdiksi negara penerima baik yurisdiksi hukum perdata, hukum pidana maupun hukum administrasi negara. ${ }^{42}$

\section{Pengertian}

keistimewaan

adalah hak istimewa (privilege) yang melekat pada perwakilan diplomatik (sebagai institusi) dan para diplomat (sebagai individu) serta keluarganya. Contoh keistimewaan diplomatik adalah pembebasan dari pajak, bea, cukai dan pungutan. ${ }^{43}$

Ada tiga teori yang menjadi landasan pemberian kekebalan dan keistimewaan diplomatik:

a. Exterritoriality theory

40 Pedoman Tertib Diplomatik dan Tertib Protokoler Departemen Luar Negeri Republik Indonesia, Departemen Luar Negeri, 1969

41 Pasal 22, 24, 29 dan 30 Konvensi Wina 1961 tentang Hubungan Diplomatik

42 Pedoman Tertib Diplomatik dan Tertib Protokoler Departemen Luar Negeri Republik Indonesia, Departemen Luar Negeri, 1969

43 Widodo, Op.Cit, hlm. 116

Lily Husni Putri, Penolakan Surat Kepercayaan (Letter of Credence) Duta Besar Negara Pengirim Oleh Negara Penerima Ditinjau dari Konvensi Wina 1961 Tentang Hubungan Diplomatik (Kasus Penolakan Surat Kepercayaan Duta Besar Indonesia Oleh Brazil)

Exterritoriality

theory menganggap bahwa diplomat dan propertinya berada di negara pengirim meskipun secara konkret berada di negara penerima. Oleh karena itu, diplomat kebal terhadap yurisdiksi hukum pidana dan hukum perdata negara penerima. ${ }^{4}$ Dengan demikian menurut teori ini, gedung perwakilan diplomatik berada di luar wilayah negara penerima. Wilayah tersebut dianggap sebagai perluasan dari wilayah negara pengirim. 45

\section{b. Representative character theory}

Representative character

theory berdasarkan pada pemikiran bahwa seorang diplomat adalah wakil negara berdaulat. Berpijak pada pola pemikiran tersebut, setiap diplomat perlu mendapatkan kekebalan agar dapat menjalankan tugas dengan baik. Menurut teori ini, diplomat dianggap sebagai perwakilan kepala negara dari negara pengirim. 46

${ }^{44}$ John R. Wood \& Jean Serres, Diplomatic Ceremonial and Protocol, Columbia University Press, New York, 1970 hlm. 134

45 Sumaryo Suryokusumo, Op.Cit,

46 Veronica L. Maginnis, Limiting Diplomatic Immunity: Lesson Learned From the 1946 Convention on the Privileges and Immunities of the United Nations, Brooklyn Journal of 
c. Functional necessity theory

Menurut functional necessity theory, kekebalan dan keistimewaan diplomatik perlu diberikan kepada diplomat agar dapat melaksanakan tugasnya dengan baik. ${ }^{47}$ Functional necessity theory adalah teori yang paling rasional dan paling benar dalam menjustifikasi pemberian kekebalan dan keistimewaan diplomatik. Hal ini sesuai dengan pendapat Gerald Fitzmaurice sebagai salah seorang rapporteur khusus yang ditunjuk oleh Komisi Hukum Internasional untuk ikut merumuskan rancangan Konvensi Wina 1961 tentang Hubungan Diplomatik menegaskan bahwa functional necessity theory adalah satu-satunya teori yang paling memuaskan dan juga benar dalam menjelaskan dasar pemberian kekebalan dan keistimewaan diplomatik, karena tanpa adanya kekebalan dan keistimewaan diplomatik, diplomat tidak dapat menjalankan tugasnya di negara penerima. ${ }^{48}$

International Law, Vol. 28, Issue 3, 2003, hlm. 995

47 Antonio Cassese, International Law, 2nd Edition, Oxford University Press, Oxford, 2005, hlm. 114 hlm. 135 48 Sumaryo Suryokusumo, Op.Cit, Lily Husni Putri, Penolakan Surat Kepercayaan (Letter of Credence) Duta Besar Negara Pengirim Oleh Negara Penerima Ditinjau dari Konvensi Wina 1961 Tentang Hubungan Diplomatik (Kasus Penolakan Surat Kepercayaan Duta Besar Indonesia Oleh Brazil)
Konvensi Wina 1961 tentang Hubungan Diplomatik menganut functional necessity theory. Hal ini dapat dilihat pada pembukaan (preamble) Konvensi Wina 1961 tentang Hubungan Diplomatik:

“...the purpose of such privileges and immunities is not to benefit individuals but to ensure the efficient performance of the functions of diplomatic missions as representing states." 49

\section{Tata Cara Pembukaan} Hubungan Diplomatik dan Fungsi Surat Kepercayaan (Letter of Credence) dalam Pengangkatan Duta Besar Sebagai Kepala

\section{Perwakilan Diplomatik}

Dalam hukum internasional, setiap negara yang merdeka dan berdaulat mempunyai hak menerima dan mengirimkan perwakilan diplomatik (ius legationis). 50 Namun pembukaan hubungan diplomatik antar negara tergantung dari persetujuan bersama (mutual consent) diantara negara-negara yang bersangkutan. Hal ini sebagaimana dinyatakan dalam pasal 2 Konvensi Wina 1961 tentang Hubungan Diplomatik (Vienna

${ }^{49}$ Eileen Denza, Op.Cit, hlm. 10

50 Eileen Denza, Ibid, hlm. 20 
p-ISSN: 1693-766X ; e-ISSN: 2579-4663, Vol. 26, No. 2, Agustus 2017

Convention 1961 on Diplomatic mendapat persetujuan dari Senat. ${ }^{54}$

Relations):

"The establishment of diplomatic Di Indonesia, pengangkatan seorang relations between states, and of duta besar dilakukan oleh presiden permanent diplomatic missions, takes place by mutual consent."

Kesepakatan ini dituangkan dalam bentuk komunike bersama (joint communique), persetujuan bersama (joint agreement) atau deklarasi bersama (joint declaration). ${ }^{51}$ Setelah ada kesepakatan untuk membuka hubungan diplomatik dan perwakilan diplomatik maka perlu ditunjuk seorang Kepala Perwakilan Diplomatik. Sekarang ini kepala perwakilan pada tingkat duta besar merupakan praktek yang biasa berlaku. ${ }^{52}$

Pengangkatan calon duta besar tidak sama di setiap negara, tergantung dari sistem ketatanegaraan yang berlaku di suatu negara. ${ }^{53}$ Di Amerika Serikat, presiden sebagai kepala eksekutif mengangkat duta besar tetapi pengangkatan duta besar harus

${ }^{51}$ Syahmin Ak, Op.Cit, hlm. 40

52 Boer Mauna, Hukum Internasional: Pengertian, Peranan dan Fungsi dalam Era Dinamika Global, Penerbit Alumni, Bandung, 2001, hlm. 479

53 B. Sen, Op.Cit, hlm. 24

dengan

memperhatikan

pertimbangan Dewan Perwakilan

Rakyat (DPR). $55 \quad$ Apabila

pengangkatan calon duta besar telah diputuskan, namanya diajukan kepada pemerintah negara penerima oleh negara pengirim untuk mendapatkan agrément. 56 Agrément adalah pemberitahuan negara penerima kepada negara pengirim mengenai penerimaan calon duta besar (ambassador designate) yang diajukan atau dinyatakan persona grata. ${ }^{57}$ Keharusan adanya agrément 54 Article II Section 2 (2) US Constitution:

"The President...by and with the advice and consent of the Senate, shall appoint ambassadors, other public ministers and consuls..."

55 Pasal 13 ayat (2) Perubahan Pertama Undang-Undang Dasar Negara Republik Indonesia 1945 menyatakan:

(2) "Dalam hal mengangkat duta, Presiden memperhatikan pertimbangan Dewan Perwakilan Rakyat"

56 Pasal 4 ayat (1) Konvensi Wina 1961 tentang Hubungan Diplomatik (Vienna Convention 1961 on Diplomatic Relations) menyatakan:

(1) "The sending State must make certain that the agrement of the receiving State has been given for the person it proposes it accredit as head of the mission to that State"

57 Masyhur Effendi, Hukum Konsuler, Hukum Diplomatik Serta Hak dan Kewajiban Wakil-Wakil Organisasi Internasional/Negara, IKIP Malang, Malang, 1994, hlm. 31

Lily Husni Putri, Penolakan Surat Kepercayaan (Letter of Credence) Duta Besar Negara Pengirim Oleh Negara Penerima Ditinjau dari Konvensi Wina 1961 Tentang Hubungan Diplomatik (Kasus Penolakan Surat Kepercayaan Duta Besar Indonesia Oleh Brazil) 
dari negara penerima terhadap calon duta besar yang diajukan oleh negara pengirim ditentukan dalam pasal 4 ayat (1) Konvensi Wina 1961 tentang Hubungan Diplomatik (Vienna Convention 1969 on Diplomatic Relations):

"The sending state must make certain that the agrement of the receiving state has been given for the person it proposes to accredit as head of the mission to that state"

Setelah memperoleh agrément dari negara penerima, negara pengirim mengeluarkan surat kepercayaan (letter of credence). Menurut L. Dembinski, surat kepercayaan (letter of credence) adalah bentuk tradisional dari surat kuasa (full powers) yang dikeluarkan oleh kepala negara pengirim yang ditujukan kepada kepala negara penerima. 58 Dengan menggunakan surat kepercayaan (letter of credence), kepala negara pengirim mengakreditasikan seorang duta besar atau minister ke negara penerima. $59 \mathrm{Di}$ Indonesia, acuan normatif mengenai surat

58 L. Dembinski, The Modern Law of Diplomacy: External Missions of States and International Organizations, Martinus Nijhoff, Dordrecht, Boston, 1988, hlm. 101 hlm. 162

59 R. Jennings \& A. Watts, Op.Cit, kepercayaan (credential atau letter of credence) ada didalam UndangUndang No. 37 Tahun 1999 tentang Hubungan Luar Negeri. Menurut pasal 35 ayat (1) Undang-Undang No. 37 Tahun 1999 tentang Hubungan Luar Negeri presiden memberikan surat kepercayaan kepada Duta Besar Luar Biasa dan Berkuasa Penuh Republik Indonesia untuk suatu negara tertentu atau pada suatu organisasi internasional dan menerima surat kepercayaan (letter of credence) dari kepala negara asing bagi pengangkatan Duta Besar dan Berkuasa Penuh negara tersebut untuk Indonesia.

Menurut pasal 13 ayat (1) Konvensi Wina 1961 tentang Hubungan Diplomatik (Vienna Convention 1969 on Diplomatic Relations), seorang kepala perwakilan diplomatik dianggap telah mulai melaksanakan tugasnya di negara penerima setelah menyerahkan surat kepercayaan (letter of credence) kepada kepala negara atau kepala pemerintahan negara penerima atau setelah memberitahukan kedatangannya dan menyerahkan salinan surat kepercayaan (letter of credence)

Lily Husni Putri, Penolakan Surat Kepercayaan (Letter of Credence) Duta Besar Negara Pengirim Oleh Negara Penerima Ditinjau dari Konvensi Wina 1961 Tentang Hubungan Diplomatik (Kasus Penolakan Surat Kepercayaan Duta Besar Indonesia Oleh Brazil) 
p-ISSN: 1693-766X ; e-ISSN: 2579-4663, Vol. 26, No. 2, Agustus 2017

kepada Kementerian Luar Negeri Besar Republik Indonesia untuk negara penerima. 60

Brazil adalah Toto Riyanto.

4. Penolakan Penerimaan Surat mempunyai hak untuk menolak Kepercayaan (Letter of seorang calon duta besar dan Credence) Duta Besar penolakan seorang calon duta besar Indonesia untuk Brazil oleh negara pengirim oleh negara Pemerintah Brazil Menurut penerima bukan saja sebelum Konvensi Wina 1961 tentang memperoleh agrément tetapi dapat Hubungan Diplomatik (Vienna pula terjadi setelah calon duta besar Convention 1961 on memperoleh agrément. ${ }^{61}$ Agrément

\section{Diplomatic Relations)}

Sebagaimana telah dibahas sebelumnya, negara pengirim harus memperoleh kepastian bahwa negara penerima memberikan persetujuan bagi orang yang diusulkan untuk diakreditasikan sebagai kepala perwakilan diplomatik di negara penerima. Jika dilihat dari tahap-tahap pembukaan hubungan diplomatik, Indonesia dan Brazil sebelumnya telah sepakat bahwa yang akan menjadi Duta

60 Pasal 13 ayat (1) Konvensi Wina 1961 tentang Hubungan Diplomatik (Vienna Convention 1961 on Diplomatic Relations) menyatakan:

(1) The head of the mission is considered as having taken up his functions in the receiving state either when he has presented his credentials or when he has notified his arrival and a true copy of his credentials has been presented to the Ministry of Foreign Affairs of the receiving state, or such other ministry as may be agreed, in accordance with the practice prevailing in the receiving state which shall be applied in a uniform manner"

Lily Husni Putri, Penolakan Surat Kepercayaan (Letter of Credence) Duta Besar Negara Pengirim Oleh Negara Penerima Ditinjau dari Konvensi Wina 1961 Tentang Hubungan Diplomatik (Kasus Penolakan Surat Kepercayaan Duta Besar Indonesia Oleh Brazil) dapat dicabut kembali oleh negara penerima setelah diberikan asalkan calon duta besar belum sampai di negara penerima. Apabila calon duta besar yang bersangkutan sudah tiba di negara penerima dan bahkan telah siap untuk menyerahkan surat kepercayaan (letter of credence), maka negara penerima dapat menyatakan calon duta besar tersebut persona non grata. 62 Dengan demikian, tindakan Brazil yang menunda untuk menerima surat kepercayaan (letter of credence) duta besar Republik Indonesia adalah pernyataan persona non grata. Situasi semacam ini merupakan peristiwa yang jarang terjadi dan bisa dianggap eksepsional karena tidak sesuai

${ }^{61}$ Sumaryo Suryokusumo, Hukum Diplomatik: Teori dan Kasus, Penerbit PT. Alumni, Bandung, 2013, hlm. 136

62 Eileen Denza, Op.Cit, hlm. 41 
dengan ketentuan pasal 4 ayat (1)

Konvensi Wina $1961 \mathrm{itu}$ sendiri.63

Istilah persona non grata

berasal dari terminologi bahasa

Latin yang secara harfiah memiliki

arti orang yang tidak disukai.

Menurut Gamboa, persona non grata

adalah:64

"an expression in reference to a

diplomat who is no longer welcomed

to the government to which he is

accredited after he has already been

received and has enter upon his duties, or before arriving in the territory of the receiving state."

Dalam International Law Dictionary, Bledsoe dan Boleslaw mendefinisikan persona non grata sebagai: 65

"a Latin term indicating that a diplomatic agent of a state is unacceptable to the receiving state. This can take place either before the individual is accredited, indicating that the proposed appointee is unacceptable to the host state and will not be received, or after the

63 Sumaryo Suryokusumo, Hukum Diplomatik dan Konsuler, Op.Cit, hlm. 92

64 Melquiades Gamboa, $A$ Dictionary of International Law and Diplomacy, Phoenix Press, Quezon City, Philippines, 1973, hlm. 210-211

65 Robert Bledsoe \& Boleslaw Boczek, The International Law Dictionary, ABC - CLIO, Santa Barbara, CA, 1987, hlm. 112

Lily Husni Putri, Penolakan Surat Kepercayaan (Letter of Credence) Duta Besar Negara Pengirim Oleh Negara Penerima Ditinjau dari Konvensi Wina 1961 Tentang Hubungan Diplomatik (Kasus Penolakan Surat Kepercayaan Duta Besar Indonesia Oleh Brazil)

accreditation process in response to some real or alleged impropriety by the diplomatic agent."

Ketentuan mengenai persona non grata terdapat dalam pasal 9 Konvensi Wina 1961 tentang Hubungan Dipomatik (Vienna Convention 1961 on Diplomatic Relations). Pasal 9 ayat (1) Konvensi Wina 1961 tentang Hubungan Diplomatik (Vienna Convention 1961 on Diplomatic Relations) menyatakan: "The receiving state may at any time and without having to explain its decision, notify the sending state that the head of the mission or any member of the diplomatic staff of the mission is persona non grata or that any other member of the staff of the mission is not acceptable. In any such case, the sending state shall, as appropriate, either recall the person concerned or terminate his functions with the mission. A person may declare non grata or not acceptable before arriving in the territory of the receiving state."

Ketentuan mengenai persona non grata terdapat dalam pasal 9 Konvensi Wina 1961 tentang Hubungan Dipomatik (Vienna Convention 1961 on Diplomatic Relations). Pasal 9 ayat (1) Konvensi Wina 1961 tentang Hubungan 
Diplomatik (Vienna Convention 1961 on Diplomatic Relations) menyatakan: "The receiving state may at any time and without having to explain its decision, notify the sending state that the head of the mission or any member of the diplomatic staff of the mission is persona non grata or that any other member of the staff of the mission is not acceptable. In any such case, the sending state shall, as appropriate, either recall the person concerned or terminate his functions with the mission. A person may declare non grata or not acceptable before arriving in the territory of the receiving state."

Dari ketentuan pasal 9 (1) di atas, ada 3 hal yang dapat disimpulkan; pertama, negara penerima dapat sewaktu-waktu menyatakan seorang diplomat dari negara pengirim persona non grata; kedua, negara penerima tidak berkewajiban memberikan alasan persona non grata; ketiga, negara penerima dapat menyatakan seorang diplomat negara pengirim persona non grata bahkan sebelum diplomat tersebut sampai di negara penerima.

Pernyataan persona non grata negara penerima terhadap diplomat negara pengirim merupakan tindakan diskresi (discretionary act).
Oleh sebab itu negara penerima diberi kebebasan untuk menentukan alasan-alasan penyebab pernyataan persona non grata terhadap diplomat negara pengirim. Menurut Jean d'Aspremont ada dua faktor yang menyebabkan pernyataan persona non grata negara penerima terhadap diplomat negara pengirim: pertama; tingkah laku pribadi diplomat itu sendiri. Pernyataan persona non grata tersebut muncul karena diplomat yang bersangkutan melanggar hukum negara penerima dan melakukan kegiatan-kegiatan yang bersifat subversif dan intervensi yang merugikan negara penerima misalnya melakukan spionase, terorisme atau perdagangan narkotika dan obatobatan berbahaya serta ikut campur dalam urusan dalam negeri negara penerima. 66 Kegiatan-kegiatan tersebut bertentangan dengan kewajiban diplomat untuk menghormati undang-undang dan peraturan negara penerima dan tidak ikut campur dalam urusan dalam negeri negara penerima yang tercantum dalam pasal 41 ayat (1)

66 Jean d'Aspermont, Persona Non Grata, dalam Max Planck Encyclopedia of Public International Law (R. Wolfrum, ed), Oxford University Press, 2009, hlm. 3

Lily Husni Putri, Penolakan Surat Kepercayaan (Letter of Credence) Duta Besar Negara Pengirim Oleh Negara Penerima Ditinjau dari Konvensi Wina 1961 Tentang Hubungan Diplomatik (Kasus Penolakan Surat Kepercayaan Duta Besar Indonesia Oleh Brazil) 
p-ISSN: 1693-766X ; e-ISSN: 2579-4663, Vol. 26, No. 2, Agustus 2017

Konvensi Wina 1961 tentang laku atau tindakan negara pengirim

Hubungan Diplomatik (Vienna bukan karena ketidaksukaan negara

Convention 1961 on Diplomatic penerima terhadap pribadi diplomat

Relations). 67 Pada tahun 1995 tersebut. Inilah yang terjadi dalam

Inggris menyatakan seorang atase di kasus Duta Besar Toto Riyanto.

kedutaan besar Iraq persona non Penolakan Brazil terhadap Duta

grata karena dituduh Besar Toto Riyanto bersifat politis

mengumpulkan informasi untuk terkait eksekusi mati warga negara

direktorat intelijen tentang Brazil oleh pemerintah Indonesia.

mahasiswa-mahasiswa yang Ketidaksukaan Brazil tersebut

menentang rezim Saddam Hussein. bukan kepada pribadi Duta Besar

Pada tahun 1999 Republik Toto Riyanto melainkan kepada

Demokratik Kongo menyatakan kebijakan pemerintah Indonesia

seorang diplomat Inggris persona yang melaksanakan hukuman mati non grata karena spionase.68 terhadap warganya. Contoh lain

Kedua; tingkah laku atau adalah ketika Inggris menyatakan tindakan negara pengirim. ${ }^{69}$ Dalam persona non grata dan mengusir hal ini, negara penerima empat diplomat Rusia sebagai menggunakan persona non grata respon atas penolakan Rusia untuk sebagai bentuk ketidaksepahaman mengekstradisi Andrey Lugoyov dengan negara pengirim mengenai untuk diadili di Inggris karena masalah yang bersifat politis. Jadi, pembunuhan Alexander Litvinov negara penerima menyatakan yang tewas dengan cara diracun diplomat negara pengirim persona pada tahun 2007 di London. ${ }^{70}$

non grata disebabkan oleh tingkah

67 Pasal 41 ayat (1) Konvensi Wina 1961 tentang Hubungan Diplomatik (Vienna Convention 1961 on Diplomatic Relations) menyatakan:

(1). Without prejudice to their privileges and immunities, it is the duty of all persons enjoying such privileges and immunities to respect the laws and regulations of the receiving state. They also have a duty not to interfere in the internal affairs of that state. 4 68 Jean d'Aspermont, Op.Cit, hlm. 69 Ibid
Lily Husni Putri, Penolakan Surat Kepercayaan (Letter of Credence) Duta Besar

Dengan demikian, tidak ada ketentuan Konvensi Wina 1961 tentang Hubungan Diplomatik (Vienna Convention 1961 on Diplomatic Relations) yang dilanggar oleh Brazil. Namun dari sisi diplomasi tindakan Brazil tidak lazim dan melanggar tata krama berdiplomasi sebab Brazil Negara Pengirim Oleh Negara Penerima Ditinjau dari Konvensi Wina 1961 Tentang Hubungan Diplomatik (Kasus Penolakan Surat Kepercayaan Duta Besar Indonesia Oleh Brazil) 
membatalkan prosesi penyerahan dipisahkan dari nilai-nilai moral surat kepercayaan (letter of credence) atau etika. 71 Sesungguhnya, Duta Besar Republik Indonesia pada moralitas internasional (kebiasaan, saat proses protokoler sudah prinsip umum dan tata krama berjalan dan Duta Besar Republik [comity] internasional sebagai bagian Indonesia telah berada di Istana dari moralitas internasional) telah Kepresidenan Brazil. Tindakan menjadi sumber hukum Brazil tersebut juga beresiko internasional yang penting. ${ }^{72}$ merusak hubungan Indonesia-Brazil yang telah lama terjalin dan saling menguntungkan.

\section{SIMPULAN}

Meskipun tidak etis dan beresiko merusak hubungan kedua negara, Brazil tidak melanggar aturan hukum internasional tentang hubungan diplomatik yang terdapat dalam Konvensi Wina 1961. Aturan hukum internasional harus dibedakan dari tata krama (comity) internasional karena tata krama atau kesopanan tidak mengikat. Dalam masyarakat internasional, tingkah laku negara diatur oleh hukum internasional dan moralitas internasional. Hukum internasional sebagai aturan legal dan moralitas internasional sebagai kode moral. Hukum internasional bersifat legal, baik dari sudut isi maupun bentuk, sementara konsep moralitas internasional merupakan cabang dari etika. Namun ini tidak berarti bahwa hukum internasional dapat

Lily Husni Putri, Penolakan Surat Kepercayaan (Letter of Credence) Duta Besar Negara Pengirim Oleh Negara Penerima Ditinjau dari Konvensi Wina 1961 Tentang Hubungan Diplomatik (Kasus Penolakan Surat Kepercayaan Duta Besar Indonesia Oleh Brazil) 


\section{DAFTAR PUSTAKA}

Antara, "Nuruzahri Bebas Ancaman Hukuman Mati di Malaysia", http://www.antaranews.com/b erita/409467/nuruzahribebas-ancaman-hukumanmati-di-malaysia

Antara, "Soal Penarikan Duta Besar Indonesia Untuk Brasil", http:/ /www.antaranews.com/b erita/481892/soal-penarikanduta-besar-indonesia-untukbrasil

Antonio Cassese, International Law, 2nd Edition, Oxford University Press, Oxford, 2005

Boer Mauna, Hukum Internasional: Pengertian, Peranan dan Fungsi Dalam Era Dinamika Global, Penerbit Alumni, Bandung, 2001

B. Sen, A Diplomat Handbook's of International Law and Practices, Martinus Nijhoff, The Hague, 1965

CNN Indonesia, "Rodrigo Gularte: Peselancar Pesakitan Yang Menanti Mati”, http://www.cnnindonesia.com /nasional/2015042819174212-49841/rodrigo-gulartepeselancar-pesakitan-yangmenanti-mati/

Dinesh, "International Morality: Role of International Morality in International Politics",

http:/ / www.yourarticlelibrary.c om/internationalpolitics/international-moralityrole-of-international-moralityin-internationalpolitics /48485/

Dumitru Mazilu, Treaty Regerding Negotiation: Theory and Practice, Lumina Lex Publishing House, Bucharest, 2002

Eileen Denza, Diplomatic Law: A Commentary on the Vienna Convention on Diplomatic Relations, 2nd Edition, Oxford University Press, New York, 2002

Frederick H. Hartmann, The Relations of Nations, MacMillan Publishing Company, New York, 1987

Gerhard Von Glahn, Law Among Nations: An Introduction to Public International Law, MacMillan Publishing Company, New York, 1976

Gheorge Iacob, Introduction in Diplomacy, Foundation Axis Publisihing House, Iasi, 1997

GVG Khrisnamurty, Modern Diplomacy, Dialect and Dimension, Sagar Publication, New Delhi, 1968

Hugh Gibson, The Road to Foreign Policy, Doubleday, New York, 1994

Jean d'Aspermont, Persona Non Grata, Max Planck Encyclopedia of Public International Law (R. Wolfrum, ed), Oxford University Press, 2009

Lily Husni Putri, Penolakan Surat Kepercayaan (Letter of Credence) Duta Besar Negara Pengirim Oleh Negara Penerima Ditinjau dari Konvensi Wina 1961 Tentang Hubungan Diplomatik (Kasus Penolakan Surat Kepercayaan Duta Besar Indonesia Oleh Brazil) 
John O’Brien, International Law, Cavendish Publishing Limited, London, 2001

John R. Wood \& Jean Serres, Diplomatic Ceremonial and Protocol, Colimbia University Press, New York, 1970

Kompas, "Hingga Saat Terakhir Rodrigo Gularte Tak Sadar Akan Dieksekusi”, http://internasional.kompas.co $\mathrm{m} / \mathrm{read} / 2015 / 04 / 30 / 1146497$ 1/Hingga.Saat.Terakhir.Rodrig o.Gularte.Tak.Sadar.Akan.Diek sekusi

L. Dembinski, The Modern Law of Diplomacy: External Mission of States and International Organizations, martinus Nijhoff, Dordrecht, Boston, 1988

Malcolm N. Shaw, International Law, 6th Edition, Cambridge University Press, 2008

Masyhur Effendi, Hukum Konsuler, Hukum Diplomatik Serta Hak dan Kewajiban Wakil-Wakil Organisasi

Internasional/Negara, IKIP Malang, Malang, 1994

Melquiades Gamboa, A Dictionary of International Law and Diplomacy, Phoenix Press, Quezon City, Philippines, 1973

Merdeka, "TNI AU Berharap Pembelian Super Tucano dari Brasil Jalan Terus", https://www.merdeka.com/per istiwa/tni-au-berharappembelian-super-tucano-daribrasil-jalan-terus.html

Norman D. Palmer \& Howard C. Perkins, International
Relations: The World Community in Transition, Houghton Mifflin, Boston, Massachusetts, 1957

Republika, "Kisah Terpidana Mati (1): Dari Pilot Jadi Bandar Narkotika", http://www.republika.co.id/be rita/nasional/hukum/15/01/1 7/niabv3-kisah-terpidanamati-1-dari-pilot-jadi-bandarnarkotika

Robert Bledsoe \& Boleslaw Boczek, The International Law Dictionary, ABC-CLIO, Santa Barbara, California, 1987

R. Jennings \& A. Watts, Oppenheim's International Law Volume I: Peace, 9th Edition, Longman, London, New York, 1997

Sumaryo Suryokusumo, Hukum Diplomatik dan Konsuler Jilid I, Tatanusa, Jakarta, 2013

Sumaryo Suryokusumo, Hukum Diplomatik: Teori dan Kasus, Penerbit PT. Alumni, Bandung, 2013

Syahmin Ak, Hukum Diplomatik: Suatu Pengantar, Armico, Bandung, 1998

Tempo, "Gembong Narkoba Ini Menangis Sebelum Dieksekusi Mati",

https://m.tempo.co/read/news 12015/02/24/063644768/gem bong-narkoba-ini-menangissebelum-dieksekusi-mati

Tempo, "Menit Terakhir Terpidana Mati: Romo, Saya Akan Dieksekusi?”, https://m.tempo.co/read/news 2015/04/30/063662297/men

Lily Husni Putri, Penolakan Surat Kepercayaan (Letter of Credence) Duta Besar Negara Pengirim Oleh Negara Penerima Ditinjau dari Konvensi Wina 1961 Tentang Hubungan Diplomatik (Kasus Penolakan Surat Kepercayaan Duta Besar Indonesia Oleh Brazil) 
it-terakhir-terpidana-matiromo-saya-akan-dieksekusi

Tempo, "Protes Eksekusi, Dubes Brasil Ditarik dari Jakarta", https://m.tempo.co/read/news /2015/01/18/063635680/prot es-eksekusi-dubes-brasilditarik-dari-jakarta

The Foreign Services of the United States Department of State Publication 3612, Foreign Services Series 6, Government Printing Office, Washington DC, 1946

Tribunal of Rome, Castiglioni vs Federal People's Republic of Yugoslavia Case No. 43, 1952, Italy
Veronica L. Maginnis, Limiting Diplomatic Immunity: Lesson learned From the 1946 Convention on the Privileges and Immunities of the United Nations, Brooklyn Journal of International Law, Vol. 28, Issue 3, 2003

Widodo, Hukum Diplomatik dan Konsuler Pada Era Globalisasi, CV. Aswaja Presindo, Yogyakarta, 2012

Konvensi Wina 1961 tentang Hubungan Diplomatik

Pedoman Tertib Diplomatik dan Tertib Protokoler Departemen Luar Negeri Republik Indonesia 1969

Undang-Undang Dasar 1945 Amandemen I

US

Constitution

Lily Husni Putri, Penolakan Surat Kepercayaan (Letter of Credence) Duta Besar Negara Pengirim Oleh Negara Penerima Ditinjau dari Konvensi Wina 1961 Tentang Hubungan Diplomatik (Kasus Penolakan Surat Kepercayaan Duta Besar Indonesia Oleh Brazil) 